\title{
Extravert individualists or introvert collectivists? Personality traits and individualism and collectivism in students in Poland and Ukraine
}

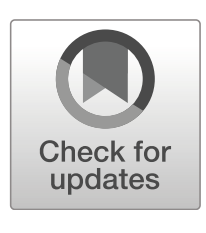

\author{
Anna Tychmanowicz ${ }^{1} \cdot$ Sara Filipiak $^{2} \cdot$ Zoriana Sprynska $^{3}$ \\ Published online: 15 November 2019 \\ (C) The Author(s) 2019
}

\begin{abstract}
The aim of this research was to analyse the connections between personality traits and horizontal and vertical forms of individualism and collectivism, regarded as social orientations, in two national groups of students. The analyses were conducted in the context of psychosocial functioning in the academic environment. A total of 210 students were examined including 109 of Polish nationality and 101 of Ukrainian nationality. Despite the historical and geographical proximity of both countries, we predicted that different relationships between variables will occur in the two samples of students. The following tests were used: the Ten Item Personality Inventory (TIPI) and the Vertical- Horizontal Individualism-Collectivism Scale (KIRH) in Polish and Ukrainian versions. The results indicated that Polish students had significantly higher horizontal orientation, both in individualism and collectivism, compared to their Ukrainian colleagues. Polish students were also more agreeable and open to experience than Ukrainian students. There were significantly different patterns of correlations between the analysed variables in the two national groups. The obtained z-statistics revealed differences between groups in correlations between the vertical form of both individualism and collectivism and such personality traits as extraversion, emotional stability, and openness to experience. There was also a significant difference between the relationships of horizontal individualism and agreeableness in two compared groups. Regression analyses indicated various significant predictors of social orientations in the two groups.
\end{abstract}

Keywords Polish and Ukrainian students · Personality traits · Horizontal and vertical individualism and collectivism · Social orientations

Anna Tychmanowicz

anna.tychmanowicz@poczta.umcs.pl

Sara Filipiak

anna.tychmanowicz@poczta.umcs.pl

Zoriana Sprynska

zoriaspr@gmail.com

1 Department of Psychology of Emotions and Personality, Maria Curie-Skłodowska University, Plac Litewski 5, 20-080 Lublin, Poland

2 Department of Clinical Psychology and Neuropsychology, Maria Curie-Skłodowska University, Plac Litewski 5, 20-080 Lublin, Poland

3 Ivan Franko Pedagogical State University, Ivan Franko 24, Drohobycz, Ukraine

\section{Introduction}

\section{Individualism and Collectivism}

The construct of individualism and collectivism, developed by Triandis $(1989,2001)$, is used to describe both cultural and individual differences (see Boski 2010). It is worth mentioning that Triandis et al. (Triandis et al. 1985; Triandis 1989, 2001,2018 ) suggest that the terms individualism and collectivism should be foremost used to depict cultures and societies, while the terms idiocentrism and allocentrism should be used to characterise individual differences. However, there is still a tendency in the literature to use the terms individualism and collectivism in reference to an individual's traits (e.g., Adamska et al. 2005; Realo et al. 1997; Singelis et al. 1995; Vogt 2007; Vogt and Laher 2009). It is documented that within particular cultures (individualist or collectivist), there might be persons with different levels of these traits (Triandis et al. 1985; Triandis 1989, 2018). However, one would expect more individualistic persons in individualist cultures and more collectivistic persons in collectivist cultures (Triandis 2001). In 
individualistic cultures such as societies in North America and North and Western Europe, attaining personal goals and benefits is highlighted, whereas in collectivist cultures such as in South America, Africa, and Asia, the emphasis is on reaching group targets and outcomes (Hofstede 2001; Triandis 1989, 2001, 2018).

Both individualism and collectivism have two forms, vertical and horizontal. Vertical collectivism refers to perceiving oneself as a part of the collective and accepting inequalities within the group. Horizontal collectivism refers to perceiving oneself as a part of a group in which everybody is equal. Vertical individualism stresses the individual's autonomy and inequality of group members. Horizontal individualism also highlights the individual's autonomy, but it assumes equality of group members (Singelis et al. 1995; Triandis 1995, 2018; Brewer and Chen 2007; Zarzycka et al. 2016).

\section{Personality Traits}

The most popular concept in personality research in contemporary psychology is the Big Five model, which specifies five traits: Extraversion, Neuroticism, Agreeableness, Conscientiousness, and Openness to Experience/Intellect (McCrae and Costa 1996; Hosseinkhanzadeh and Taher 2013; Vogt 2007). Extraversion is a dimension of personality that manifests in the number and quality of interpersonal relations and the tendency to gain pleasure from being with other people. Neuroticism refers to emotional instability. People with high neuroticism manifest a tendency to experience negative emotions such as anxiety or anger. Their behaviour might be unpredictable and reactions might be impulsive. Low neuroticism pertains to emotional control and good personal adjustment. Agreeableness refers to the way people treat others. High agreeableness is linked to altruistic behaviours and seeking cooperation instead of rivalry. Conscientiousness refers to the intensity of traits such as diligence, assiduity, patience during work, and delaying immediate gratification instead of long-term benefits. Openness to experience refers to the tendency to seek novelty, stimulation or new experiences. This dimension of personality is in itself heterogenous as it refers both to cognitive traits such as creativity, divergent thinking and versatility and to more emotional features such as bravery and nonconformity. People with low openness to experience prefer stable and predictable environments. These five traits of personality are regarded as "basic tendencies" because they are inherited and have biological sources (McCrae and Costa 1996). The same authors also mention "characteristic adaptations" (e.g., values, beliefs, habits, objectives), that are formed from the interaction of basic tendencies, experiences and environmental and cultural factors. (Benet-Martínez and Oishi 2010; Hofstede and McCrae 2004; McAdams \& Pals, 2006).

\section{Relationships Between Individualism, Collectivism, Personality and Culture}

From the 1960s to the 1990s, personality and culture research declined, but we can now observe an increase of research in this area (Benet-Martínez and Oishi 2010; McCrae 2000, 2001; Vogt and Laher 2009). Some of the reasons for the return of this interest are the establishment of the FiveFactor Model (FFM) and a focus on the connections between individualism-collectivism and personality, culture, and ecology. Moreover, international scientific collaboration became easier and, as a result, has led to a revival of cultural studies of personality (Benet-Martínez and Oishi 2010).

It is well documented that genetic factor is prevalent in the personality formation (Caspi et al. 2005; Krueger and Johnson 2010; Larsen and Buss 2010; McCrae 2000; McCrae et al. 2000). However, environmental factors are responsible for the changes of personality in ontogeny (Kamakura et al. 2007; Krueger and Johnson 2010; Gosling and Vazire 2002), in which cultural factors play a crucial role (Benet-Martínez and Oishi 2010; Triandis and Suh 2002). As Maccoby (2000) suggests, ecology forms the culture, which in turn shapes the patterns of socialisation, which are responsible for differences in human personality. Personality indeed develops in the context of a particular culture and is interconnected with the social environment (Markus and Kitayama 1998). Therefore, it is not possible to separate personality from culture because, in some sense, individuals are interdependent (with society and with groups of which they are members). Individuals are also independent, which is reflected in personality characteristics, individual abilities, motives, and objectives (Markus and Kitayama 1998). However, in different cultures, people in various ways equilibrate these aspects of functioning - for example, western cultures emphasise independence, and eastern cultures emphasise interdependence. The basic distinction between independence and inter-dependence is revealed by the concepts of individualism and collectivism developed by Triandis $(1989,2001)$, who regards these concepts as the most significant sources of cultural difference.

Some research (Allik and McCrae 2004; Chan 2006; Church 2000; Cheung et al. 2001; Vogt and Laher 2009) suggests differences in personality in different societies, which Costa and McCrae (2004) interpret as a result of the differences between Western individualist culture and Asian collectivist culture. McCrae and Allik (2002) added that some research was conducted in different countries, but the obtained differences of personality are not the result of cultural differences. Based on research conducted in 36 cultures, Allik and McCrae (2004) noticed that geographic proximity is related to similar personality profiles. Moreover, they compared profiles of Americans, Europeans, Africans, and Asians, and it turned out that Americans and Europeans were more extraverted and open to experience and less agreeable. The results were 
discussed in terms of effects of acculturation and genetic differences (Allik and McCrae 2004). Similarity of personality in societies close to each other might have different underpinnings such as similar genes, similar culture, and ecological aspects of the environment (Allik and McCrae 2004; Triandis 2001). The relationships between cultures and personality might be mutual (McCrae and Allik 2002). Cultural influences are revealed in the internalisation of ethos, which is typical in a particular culture, and childhood experiences, which are culturally shaped. These early experiences in turn form adult personality, which have a direct impact on culture and social trends (Benet-Martínez and Oishi 2010). It seems that in a contemporary global world, where borders between countries are disappearing and cultures mingle among one another, the present research might outline new directions for investigation of links between collectivism, individualism, and personality traits among students in cross-cultural psychology.

Previous research has insufficiently analysed the relations of personality traits with individualism and collectivism. Moreover, research has so far concerned countries differentiated in terms of culture such as Estonia (Realo et al. 1997), Singapore, Australia (Ward et al. 2004), South Africa (Vogt 2007; Vogt and Laher 2009). To our knowledge, there is a lack of research concerning the variables that were analysed in the present research, which was conducted in Poland and Ukraine.

Although these countries do not always entail different cultures (see Allik and McCrae 2004; Fiske 2002), Poland and Ukraine differ in cultural terms. These countries are neighbours, but they are located in different places in the cultural map of the word (Boski 2010; Kwiatkowska 2009), and they differ in terms of cultural value orientation (Schwartz 2008). Ukraine is a more Balkan and Eastern culture, while Poland is a more East-Central and Baltic culture. This means that countries from the Baltic or with an East-Central background (such as Poland) have higher historical and economical bonds to Western Europe and experienced lower communism, and they regained national independence earlier (Schwartz 2008). As a consequence, the cultural profiles of these countries are more proximate to western countries. In turn, countries with East European and Balkan culture (such as Ukraine) have fewer links to western countries but stronger historical relations with the Ottoman Empire. Moreover, the Ukraine was influenced by communism for a longer time (Schwartz 2008). There are differences and similarities between both countries. Polish-Ukrainian relations are often difficult, complex, and tense, but on the other hand, there are numerous similarities such as ethos, tradition, and everyday problems (Chodubski 2012). Further justification for this research is the complex relationship between both countries associated with their common history, including political and social conflicts as well as contemporary cooperation between countries in the fields of trade, education, and tourism
(Barwiński 2012). These arguments constitute a scientific base for the undertaken research.

In light of these differences, current political and social changes are taking place in both countries, and we assumed the need for research in this areas. of individualistic and collectivistic orientations in the context of personality underpinnings. Especially it is worth analysing connections between personality and individualism and collectivism in young people entering adulthood in the moment of crystallisation of social attitudes, future planes and decisions concerning personal goals (see Sprynska et al. 2019; Tanner and Arnett 2016).

In this research, collectivism and individualism were tested at an individual level as features that differentiate people from each other. Connections between individualism, collectivism, and Big Five personality traits were analysed in two groups of students studying in Poland and the Ukraine.

In light of the reviewed literature, we formulated our main research question: What is the relationship between personality traits and individualism-collectivism (in horizontal and vertical forms) in Polish and Ukrainian students? In accordance with previous research (Realo et al. 1997) we expect that there will be positive relationships between Agreeableness and horizontal collectivism, because this form of collectivism encompasses accepting equalities between the members of the group. We also assumed there will be negative relationships between Openness to Experience and both forms of collectivism (e.g. Realo et al. 1997) as positive attitudes towards novelty, new experiences and changes seem not to coexist with collectivistic tendencies. We also predicted the positive connections between Extraversion (see Lynn 1981; Ward et al. 2004), and horizontal individualism due to the emphasis on autonomy and equality of people in this form of individualism. Moreover, we expected positive relationships between Conscientiousness (see McCrae and Costa 1991) and vertical form of individualism, because this dimension highlights independency, the need of rivalry and competition.

\section{Method}

\section{Participants and Procedure}

A total of 210 university students were examined, including 109 from Poland and 101 from the Ukraine. The Polish participants were aged between 19 and $24(\mathrm{M}=20.96$; $\mathrm{SD}=$ 1.53). They were students of the first through fifth years of high school education representing different fields of study such as psychology, social creativity, international relations, national security, and economics. Ukrainian participants were between 18 and 24 years old $(M=19.54 ; S D=1.72)$. They represented the following fields of studies: psychology, medicine, economics, pre-school education, geography, biology, social work, art, political science, history, pharmacy, 
veterinary medicine, international relations, law, computer science, physics, and mathematics. Like the Polish sample, they were students of the first through fifth years of high school education. It is worth mentioning that Ukrainian students start high school at the age of 18 whereas in Poland students enter high school at the age of 19 .

The others sociodemographic variables in both research groups are presented in Table 1.

This research was conducted from October 2017 to April 2018 in the territories of Poland and the Ukraine. Participation was voluntary, and verbal consent was obtained from each participant.

\section{Measures}

Two instruments were administered to assess personality traits and individualism-collectivism: the Ten Item Personality Inventory (TIPI; Gosling et al. 2003 in Polish adaptation by Sorokowska et al. 2014 and Ukrainian adaptation by Sprynska 2018) and the Vertical-Horizontal IndividualismCollectivism Scale (KIRH by Adamska et al. 2005 and its Ukrainian adaptation by Karpenko 2018). Polish and Ukrainian adaptations of the tools have been prepared according to cultural procedures of tests adaptation, including the analysis of theoretical construct, linguistic adaptation and description of psychometric properties of the tools. Linguistic translation into local languages was conducted by three independent fluent Polish and Ukrainian speakers. After the common version was established, back draft translation was conducted (see Hornowska and Paluchowski 2004; Hambleton et al. 2004; Van Widenfelt et al. 2005). The TIPI consisted of 10 items comprising five scales: Extraversion (E; e.g., "extraverted, enthusiastic"), Emotional Stability (ES; e.g., "calm, emotionally stable"), Agreeableness (A; e.g., "sympathetic, warm"), Conscientiousness (C; e.g., "dependable, self-disciplined"), and Openness to Experience (O; e.g., "open to new experiences, complex"). Participants responded to each item on a scale of $1-7(1=$ disagree strongly to $7=$ agree strongly $)$. The score for each scale was calculated by obtaining the mean of two items constituting particular scale. The reliability of subscales were as follows: $\alpha=.50$ (E), $\alpha=.66$ (ES), $\alpha=.23$ (A), $\alpha=.61(\mathrm{C}), \alpha=.56(\mathrm{O})$. Despite the fact that each dimension of personality consists of only two traits, they are versatile and measure a wide scope of traits. According to the authors of the test (Gosling et al. 2003), it was designed to quickly measure wide aspects of each personality trait. However, the presence of only two traits for each dimension lowers the reliability of the whole test (Sorokowska et al. 2014).

The KIRH consists of 39 items and measures individual differences in vertical individualism (VI), horizontal individualism (HI), vertical collectivism (VC), and horizontal collectivism (HC). Vertical individualism (e.g., "It is not possible to build a good society without rivalry") and horizontal individualism (e.g., "Everything that happens to me is my private thoughts") each had five items. Likewise, vertical collectivism (e.g., "It is important to me to maintain harmony in my group") and horizontal collectivism (e.g., "I would feel proud if my co-worker won an award") each had five items. The participant responded on a scale of 1-7 (1 = totally disagree to $7=$ totally agree). The results in particular scales were a sum of items from each scale. Cronbach's alpha reliability values were: $\alpha=.73(\mathrm{VI}), \alpha=.74(\mathrm{HI}), \alpha=.71(\mathrm{VC})$, and $\alpha=.73$ (HC) for Ukrainian students and $\alpha=.69$ (VI), $\alpha=.76(\mathrm{HI}), \alpha=.73(\mathrm{VC})$, and $\alpha=.75$ (HC) for Polish students.

\section{Results}

To investigate the scientific problem, correlation and regression analyses were conducted following examination of descriptive statistics.

At the beginning, a preliminary data analysis was carried out, and the assumptions of normality were tested with the
Table 1 Sociodemographic characteristics in the Polish sample $(n=109)$ and the Ukrainian sample $(n=101)$

\begin{tabular}{|c|c|c|c|c|c|}
\hline & & \multicolumn{2}{|c|}{ Polish sample } & \multicolumn{2}{|c|}{ Ukrainian sample } \\
\hline & & $\mathrm{n}$ & $\%$ & $\mathrm{n}$ & $\%$ \\
\hline \multirow[t]{2}{*}{ Gender } & Women & 77 & 70.64 & 57 & 56.44 \\
\hline & Men & 32 & 29.36 & 44 & 43.56 \\
\hline \multirow[t]{3}{*}{ Marital status } & Married & 5 & 4.6 & 13 & 12.87 \\
\hline & Informal relation & 49 & 44.4 & 11 & 10.95 \\
\hline & Single & 55 & 50.4 & 77 & 76.23 \\
\hline \multirow[t]{4}{*}{ Place of living } & Village & 47 & 42.6 & 48 & 47.5 \\
\hline & Town with up to 20 thousand citizens & 15 & 13.9 & 17 & 16.8 \\
\hline & Town with $20-100$ thousand citizens & 20 & 18.5 & 32 & 31.7 \\
\hline & Town with more than 100 thousand citizens & 27 & 24.77 & 4 & 3.96 \\
\hline
\end{tabular}


Table 2 Descriptive statistics for analysed variables in the Polish sample $(n=109)$ and the Ukrainian sample $(n=101)$

\begin{tabular}{|c|c|c|c|c|c|c|}
\hline & Nationality & $M$ & $S D$ & Skew & $K-S$ & $p_{k-s}$ \\
\hline \multirow[t]{2}{*}{ Vertical individualism } & Polish & 36.67 & 8.23 & .18 & .97 & .026 \\
\hline & Ukrainian & 37.56 & 11.64 & .07 & .06 & .200 \\
\hline \multirow[t]{2}{*}{ Horizontal individualism } & Polish & 46.80 & 7.85 & -.24 & .98 & .375 \\
\hline & Ukrainian & 41.46 & 14.20 & -.39 & .10 & .019 \\
\hline \multirow[t]{2}{*}{ Vertical collectivism } & Polish & 37.18 & 8.76 & -.13 & .98 & .273 \\
\hline & Ukrainian & 39.25 & 9.47 & -.58 & .10 & .107 \\
\hline \multirow[t]{2}{*}{ Horizontal collectivism } & Polish & 56.65 & 8.90 & -1.02 & .94 & .001 \\
\hline & Ukrainian & 43.52 & 12.27 & .21 & .10 & .022 \\
\hline \multirow[t]{2}{*}{ Extraversion } & Polish & 4.93 & 1.34 & -.31 & .96 & .007 \\
\hline & Ukrainian & 4.61 & 1.57 & -.40 & .11 & .004 \\
\hline \multirow[t]{2}{*}{ Emotional stability } & Polish & 3.87 & 1.74 & .06 & .95 & .001 \\
\hline & Ukrainian & 4.29 & 1.16 & -.32 & .10 & .008 \\
\hline \multirow[t]{2}{*}{ Agreeableness } & Polish & 5.02 & 1.13 & -.05 & .96 & .005 \\
\hline & Ukrainian & 4.46 & 1.37 & -.01 & .10 & .020 \\
\hline \multirow[t]{2}{*}{ Consciousness } & Polish & 4.60 & 1.53 & -.50 & .95 & .002 \\
\hline & Ukrainian & 4.82 & 1.31 & -.42 & .11 & .001 \\
\hline \multirow[t]{2}{*}{ Openness to experience } & Polish & 5.20 & 1.41 & -55 & .95 & .002 \\
\hline & Ukrainian & 4.46 & 1.35 & -.23 & .11 & .005 \\
\hline
\end{tabular}

Kolmogorov-Smirnov test. The results are included in Table 2. Descriptive statistics were analysed such as means, standard deviations, and coefficients of skewness (see Table 2).

The analysis indicates that in both national groups, the distribution of data mostly differs from normal. Normal distributions of data were identified in vertical individualism in the Ukrainian group, horizontal individualism in the Polish group, and vertical collectivism in both groups. All other variables had non-normal distributions in both cohorts.

Therefore, we subsequently used the non-parametric Mann Whitney test for further analyses. Differences between the Polish and Ukrainian samples were analysed. Significant differences were found for Horizontal Individualism ( $\mathrm{U}=$ 3785.00, $p<.05)$, Horizontal Collectivism ( $\mathrm{U}=1861.50$, $p<.001)$, Agreeableness $(\mathrm{U}=4159.00, p<.05)$, and Openness to Experience ( $\mathrm{U}=3774.50, p<.001)$. Polish students had higher scores in all of those areas.
Correlation analyses (Spearman's rho) were conducted separately for the Polish and Ukrainian samples (see Tables 3 and 4).

In the Polish sample (Table 3), Extraversion is negatively correlated with Vertical Collectivism, while Agreeableness is positively correlated with both Horizontal and Vertical Collectivism. Moreover, Consciousness is positively correlated with Vertical Individualism, Emotional Stability is positively correlated with Horizontal Collectivism, and Openness to Experience is positively correlated with Horizontal Individualism. The correlations for the Ukrainian sample are shown in Table 4.

In the Ukrainian sample, Extraversion is positively correlated with both Horizontal and Vertical Individualism, while Agreeableness is positively correlated with Horizontal Individualism and Horizontal Collectivism. Emotional Stability correlates positively with both Vertical and Horizontal Individualism and Collectivism. Openness to Experience is positively

Table 3 Correlations of personality traits and hierarchical and vertical forms of individualism and collectivism in the Polish sample $(n=109)$

\begin{tabular}{lllll}
\hline Variable & Horizontal individualism & Horizontal collectivism & Vertical collectivism & Vertical individualism \\
\hline Extraversion & .12 & .12 & $-.23^{*}$ & -.04 \\
Agreeableness & -.08 & $.23^{*}$ & $.25^{*}$ & -.01 \\
Consciousness & -.02 & .12 & .10 & $.29^{* *}$ \\
Emotional stability & .17 & $.22^{*}$ & -.12 & .01 \\
Openness to experience & $.36^{* *}$ & .04 & -.19 & .01 \\
\hline
\end{tabular}

$* p<.05 . * * p<.01 . * * * p<.001$ 
Table 4 Correlations of personality traits and hierarchical and vertical forms of individualism and collectivism in the Ukrainian sample $(n=101)$

\begin{tabular}{lllll}
\hline Variable & Horizontal individualism & Horizontal collectivism & Vertical collectivism & Vertical individualism \\
\hline Extraversion & $.31^{* *}$ & .28 & .01 & $.30^{* *}$ \\
Agreeableness & $.28^{* *}$ & $.22^{*}$ & .13 & .16 \\
Consciousness & .14 & .07 & -.06 & .07 \\
Emotional stability & $.22^{*}$ & $.30^{* *}$ & $.27^{* *}$ & $.25^{*}$ \\
Openness to experience & $.34 * *$ & .16 & .04 & $.34^{* *}$ \\
\hline
\end{tabular}

$* p<.05 . * * p<.01 . * * * p<.001$

correlated with Individualism (both Horizontal and Vertical forms).

Differences between the obtained correlations for Polish and Ukrainian students were tested with z-statistics (https:// www.psychometrica.de/correlation.html). Statistically significant differences between groups were observed in correlations between Vertical Individualism and Collectivism and traits such as Extraversion (VC: $\mathrm{z}=1.743 ; p=.041$; VI: $\mathrm{z}=-2.494 ; p=.006$ ), Emotional Stability (VC: $\mathrm{z}=-.2 .836$; $p=.002 ; \mathrm{VI}: \mathrm{z}=-1.751 ; p=.04)$, and Openness to Experience (VC: $\mathrm{z}=-1.658 ; p=.049$; VI: $\mathrm{z}=-2.455 ; p=0$. 007). There was also a significant difference between Horizontal Individualism and Agreeableness in two compared groups $(\mathrm{z}=-2.625 ; p=.004)$. There were no differences in correlations between Conscientiousness and individualism/collectivism in Polish or Ukrainian students.

In the following step, a series of multivariate analyses (multiple regression) were carried out to determine the significant predictors of individualism and collectivism in the horizontal and vertical forms. It was assumed that personality traits are predictors of both individualism and collectivism, because many authors have highlighted biological bases of personality traits and their innate nature with reference to individualism and collectivism (e.g., Krueger and Johnson 2010; Larsen and Buss 2010; McCrae 2000; McCrae et al. 2000). Multivariable regression was executed, with the predictors introduced simultaneously to the model. In the final model, only significant predictors for dependent variables are included (Bedyńska and Książek 2012; Wampold and Freund 1987). The results of the regression analyses are presented separately for the Polish sample (see Table 5) and the Ukrainian sample (see Table 6).

The data presented in Table 5 reveal that in the Polish group, Openness to Experience and Emotional Stability are significant predictors of HI, as they explain $15.4 \%$ of the variance. Emotional Stability predicts Horizontal Collectivism (6.2\% of variance), and together with Agreeableness, they explain $10.0 \%$ of the variance in VC. The only predictor of VI is Consciousness, which predicts $10.3 \%$ of its variance.

Table 5 Results of multivariable regression analyses of significant personality predictors for individualism and collectivism in the Polish sample $(n=$ 109)

\begin{tabular}{|c|c|c|c|c|c|}
\hline Predictors & $B$ & $S E B$ & $B$ & $t$ & $p$ \\
\hline & \multicolumn{5}{|c|}{ Horizontal Individualism } \\
\hline Agreeableness & -1.65 & .78 & -.23 & -2.11 & .037 \\
\hline Openness to experience & 2.57 & .60 & .45 & 4.25 & .000 \\
\hline Emotional stability & 1.56 & .52 & .33 & 3.00 & .004 \\
\hline \multicolumn{6}{|c|}{$\mathrm{R}^{2}=.185 \mathrm{~F}(5,86)=5.122 ; p<.001 \Delta \mathrm{R}^{2}=.04 \Delta \mathrm{F}=4.83$} \\
\hline & \multicolumn{5}{|c|}{ Horizontal Collectivism } \\
\hline \multicolumn{6}{|l|}{ No significant predictors } \\
\hline \multicolumn{6}{|c|}{$\mathrm{R}^{2}=.07 \mathrm{~F}(5,86)=2.331 ;$ n.s. } \\
\hline & \multicolumn{5}{|c|}{ Vertical Collectivism } \\
\hline Agreeableness & 2.73 & .92 & .34 & 2.98 & .004 \\
\hline Emotional stability & -1.31 & .61 & -.25 & -2.14 & .035 \\
\hline \multicolumn{6}{|c|}{$\mathrm{R}^{2}=.10 \mathrm{~F}(5,86)=3.012 ; p<.05 \Delta \mathrm{R}^{2}=.05 \Delta \mathrm{F}=5.16$} \\
\hline & \multicolumn{5}{|c|}{ Vertical Individualism } \\
\hline Consciousness & 1.99 & .56 & .38 & 3.56 & .001 \\
\hline \multicolumn{6}{|c|}{$\mathrm{R}^{2}=.08 \mathrm{~F}(5.84)=2.605 ; p<.05$} \\
\hline
\end{tabular}


Table 6 Results of multivariable regression analyses of significant personality predictors for individualism and collectivism in the Ukrainian sample $(n=101)$

\begin{tabular}{|c|c|c|c|c|c|}
\hline Predictors & $B$ & $S E B$ & $B$ & $t$ & $P$ \\
\hline & \multicolumn{5}{|c|}{ Horizontal Individualism } \\
\hline Openness to experience & 2.40 & 1.11 & .23 & 2.17 & .032 \\
\hline Agreeableness & 2.79 & .98 & .27 & 2.84 & .005 \\
\hline Extraversion & 2.11 & .97 & .23 & 2.17 & .032 \\
\hline \multicolumn{6}{|c|}{$\mathrm{R}^{2}=.21 \mathrm{~F}(5,95)=6.216 ; p<.001 \Delta \mathrm{R}^{2}=.04 \Delta \mathrm{F}=5.37$} \\
\hline & \multicolumn{5}{|c|}{ Horizontal Collectivism } \\
\hline Emotional stability & 2.31 & 1.10 & .22 & 2.10 & .038 \\
\hline \multicolumn{6}{|l|}{$\mathrm{R}^{2}=.07 \mathrm{~F}(5,95)=2.445 ; p<.05$} \\
\hline & \multicolumn{5}{|c|}{ Vertical Collectivism } \\
\hline Emotional stability & 2.11 & .87 & .26 & 2.43 & .017 \\
\hline \multicolumn{6}{|l|}{$\mathrm{R}^{2}=.03 \mathrm{~F}(5,95)=1.530 ; p<.05$} \\
\hline & \multicolumn{5}{|c|}{ Vertical Individualism } \\
\hline Openness to experience & 2.17 & .95 & .25 & 2.29 & .024 \\
\hline \multicolumn{6}{|l|}{$\mathrm{R}^{2}=.13 \mathrm{~F}(5,95)=3.896 ; p<.01$} \\
\hline
\end{tabular}

In the Ukrainian group, Openness to Experience, Agreeableness, and Extraversion are significant predictors of HI. Together, they explain $22.2 \%$ of the variance in HI. Emotional Stability is a significant predictor of both $\mathrm{HC}$ ( $7.4 \%$ of the variance) and $\mathrm{VC}(5.4 \%$ of the variance). Openness to Experience is a significant predictor of VI and explains $10.7 \%$ of its variance.

\section{Discussion}

The aim of this research was the investigation of personality traits and vertical and hierarchical forms of individualism and collectivism (regarded as social orientations) in groups of Polish and Ukrainian students. Both countries, despite their geographical and historical proximity, are located in different places on the world cultural map (see Boski 2010; Kwiatkowska 2009). Therefore, it was plausible to expect differences in personality traits and social orientations between these groups.

The results indicate correlations of various personality traits with horizontal and vertical individualism and collectivism in both groups. Despite the different patterns in each group, the observed links between variables in this research stand in opposition to the results conducted by Vogt and Laher (Vogt 2007; Vogt and Laher 2009) on students in South Africa. This research revealed that personality traits in the Big Five model did not correlate with individualism or collectivism. The cultural factor probably played an important role in obtaining different results in our research. South Africa and Poland are situated on different localisations in the cultural map of the world (Boski 2010; Schwartz 2004). When it comes to cultural differences within Europe, in more Protestant and Roman Catholic Baltic cultures with which Poland is associated, the emphasis is placed on individualism and realisation of personal targets (Cukur et al. 2004). In contrast, religiously conservative and orthodox Balkan cultures like the Ukraine concentrate more on the groups' targets (Schwartz 2008). In our results, Polish students had a significantly higher horizontal orientation, both in individualism and collectivism, compared to their Ukrainian colleagues. These findings are additionally confirmed by a report published by Hofstede Insight Centre (https://www.hofstedeinsights.com/country-comparison/poland, ukraine; see Hofstede et al. 2010), which stated that Ukraine is more hierarchical than Poland in terms of obedience and accordance to social inequalities. The results of the present research confirm this assumption. In the Polish group, the horizontal aspect of individualism and collectivism was significantly higher. The horizontal orientation stresses the acceptance of equality in the social status of other people for both individual and group targets. Additionally, higher scores on Agreeableness in Polish students reveals a higher tendency for compassion, empathy, and cooperation (Laursen et al. 2002) compared to their Ukrainian peers. Ukrainian students turned out to be less agreeable than Polish students, who manifest a higher tendency for competition and rivalry. This might be a result of their need for change in their lives, or it might be the corollary of the military conflict that has taken place in the Ukraine over the last few years. Higher rivalry might also be a way to fulfil their educational goals.

Some authors indicate the relationships between personality traits and coping with difficulties, diligence at work, and a tendency to experience positive over negative emotions. This, 
in turn, might have an influence on life satisfaction (Gonzáles Gutiérrez et al. 2005; Tanksale 2015). It is also documented that personality traits predict social adjustment and fulfilment of the student role (see Serebryakova et al. 2016). It is worth mentioning that studying is an important period in a young person's life, and university is a fundamental life activity among young adults. Research conducted on Polish students in their first year of secondary school education concerning social orientations by Stojanowska and Baj (2017) revealed that significant predictors of satisfaction from studying were horizontal collectivism (e.g., equal interactions with peers) and horizontal individualism connected with a sense of autonomy.

The correlation analyses of the Polish sample revealed that in this group of students lower extraversion and higher agreeableness is connected with higher scores of vertical collectivism. These individuals accept the privilege of a group with unequal status, which might account for their effective functioning in the role of a student. Agreeableness is a trait that plays a crucial role for psychological well-being, having a positive affect, and satisfactory relations with people (Laursen et al. 2002). This trait is associated with high benevolence and positive relations with others based on a concern for well-being of others and the desire for social harmony (Leitner 2009). High scores of agreeableness and low emotional stability are significant predictors of vertical collectivism in the Polish group of students. Persons with higher sensitivity and anxiety are more prone to fulfilling the demands and requirements of authorities (see Allik and McCrae 2004; Laursen et al. 2002).

Emotional stability is important in the adaptation process in high school education and educational achievements as well as in professional activities (Serebryakova et al. 2016). Moreover, emotional stability is one of the most important determinants of effective coping with stressful life situations and global difficulties such as an economic crisis, social transformation, political change, or a decrease in social safety. Citizens of the Ukraine have faced such troubles. These are not the significant differences between Ukrainian and Polish students in emotional stability.

In our research, emotional stability turned out to be a significant predictor of two social orientations - Horizontal Individualism, and Vertical Collectivism - in the Polish group. It seems to be an important trait that manifests in actions and decisions made in the situations of interdependence. In the Ukrainian group, emotional stability is a predictor of two form of Collectivism: Horizontal and Vertical. This means that in Ukrainian group emotional stability and the tolerance for frustration (see Strus et al. 2014) enable integration with the group and internalisation of its norms, independently of how people perceive status of group members. This pattern is different from that observed in the Polish group.

In the Ukrainian group, we found more relationships between personality traits and social orientations than in the Polish group. However, conscientiousness is absent in each of these relations. This means that conscientiousness does not explain individualistic or collectivistic orientation on the level of correlation and regression. Individualism, which relates to the prevalence of individual targets over group norms and goals, both in the vertical and horizontal form, is linked positively with most of the analysed personality traits with the exception of conscientiousness.

Horizontal collectivism is manifested by the care for prosperity and the group's goals without being obedient to the group (Singelis et al. 1995). The Ukrainian group is connected positively with such personality trait as Emotional Stability. This personality trait is the only significant predictor of both forms of collectivism. It means low level of anxiety, predictability of behaviour and being well-balanced coexists with regarding oneself as a part of the group and prevalence of social targets over individual ones (see Nelis et al. 2011). Openness to experience is a predictor of both forms of individualism. These results suggest that mental flexibility, creativity, imagination coexist with the autonomy in setting one's own goals and decision making (see Strus et al. 2014). People with higher levels of openness to experience are versatile and tend to perceive complex motivations for other people's behaviour (McCrae and Costa 1997). The results also indicate that agreeableness is connected with horizontal individualism. This can be explained in terms of the adaptive function of being benevolent, cheerful, and friendly toward other people to achieve personal goals.

Singelis et al. (1995) noticed that individualistic people treat interpersonal relations in a rational manner, which implies the calculation of costs and potential benefits connected with a particular interaction. It is possible that cognitive openness, positive attitudes toward people, and the readiness for cooperation enable the realisation of personal plans and goals.

These results have shed new light on previous research in this area. At the same time, due to its limitations, this line of research should continue in the future.

\section{Limitations}

There are a few limitations of this research. The first is a relatively small sample size. The research should be conducted on a larger group in the future. Moreover, we analysed the connections between personality traits and social orientations separately in Polish and Ukrainian students; in the future, an interesting area of study would be the examination of these variables in intermingled groups studying together at Polish universities. Moreover, the present research included only students from Western Ukraine. Because of the military conflict in Eastern Ukraine, personal resources such as personality traits and social orientations might be different from citizens of different parts of the Ukraine (see Serebryakova et al. 2016). This might have had an influence on the obtained results in the examined Ukrainian sample. 


\section{Conclusions}

This research was motivated by reports of increasing migration of Ukrainian students into Polish universities in the last few years. According to the Report of Foreign Students in Poland in 2017 (published on www.studyinpoland.pl), in the years 2016-2017, a total of 35,584 students from the Ukraine studied in Poland. Research on personality traits and social orientations such as individualism and collectivism in two separate groups of students could help the formulation of adequate educational demands and specification of profiles for fields of study by the universities' authorities. It would also improve the adaptation process of foreign students to a Polish academic environment and, later, the entry of young Ukrainian people into the Polish labour market.

It is worth mentioning that although Poland still incorporates western standards of living after regaining autonomy and joining the European Union, Ukraine is also undergoing social and political changes that lead to transformations in social orientations of its citizens and in the quality of their lives. This research conducted with Polish and Ukrainian students is the first stage of a long-term project aimed at investigating the determinants of quality of life among Polish and Ukrainian students, the underpinnings of social adjustment of Ukrainian students in Poland, and mutual adaptation of Polish and Ukrainian students studying together at Polish universities. Future research will examine other variables such as ethnic identity, social axioms, and personal values.

\section{Compliance with Ethical Standards}

Conflict of Interest On behalf of all authors, the corresponding author states that there is no conflict of interest.

Ethical Approval This research was approved by Ethics for Scientific Research at the Faculty of Education and Psychology at Maria CurieSkłodowska University (Opinion No 19/2019).

Open Access This article is distributed under the terms of the Creative Commons Attribution 4.0 International License (http:// creativecommons.org/licenses/by/4.0/), which permits unrestricted use, distribution, and reproduction in any medium, provided you give appropriate credit to the original author(s) and the source, provide a link to the Creative Commons license, and indicate if changes were made.

\section{References}

Adamska, K., Retowski, S., \& Konarski, R. (2005). KIRH kwestionariusz do badania kolektywizmu i indywidualizmu równościowego oraz hierarchicznego [KIRH - a questionnaire to measure horizontal and vertical collectivism and individualism]. Czasopismo Psychologiczne, [Psychological Journal], 11 (2), 179188.
Allik, J., \& McCrae, R. R. (2004). Toward a geography of personality traits: Patterns of profiles across 36 cultures. Journal of CrossCultural Psychology, 35(1), 13-28.

Barwiński, M. (2012). Stosunki międzypaństwowe Polski z Ukrainą, Białorusią i Litwą po 1990 roku w kontekście sytuacji mniejszości narodowych. [Polish interstate relations with Ukraine, Belarus and Lithuania after 1990 in the context of national minorities]. Studia $z$ Geografii Politycznej i Historycznej, [Studies of Political and Historical Geography], 1, 139-166.

Bedyńska, S., \& Książek, M. (2012). Statystyczny drogowskaz. Tom 3. [Statistical Guide. Part 3]. Warszawa: Wydawnictwo Akademickie Sedno-Spółka z.o.o.

Benet-Martínez, V., \& Oishi, S. (2010). Culture and personality. In O. P. John, R. W. Robins, \& L. A. Pervin (Eds.), Handbook of personality: Theory and research (pp. 542-567). New York-London: The Guilford Press.

Boski, P. (2010). Kulturowe ramy zachowań społecznych [The Cultural framework of Social Behaviours]. Warszawa: Wydawnictwo Naukowe PWN.

Brewer, M. B., \& Chen, Y. R. (2007). Where (who) are collectives in collectivism? Toward conceptual clarification of individualism and collectivism. Psychological Review, 114(1), 133-151.

Caspi, A., Roberts, B. W., \& Shiner, R. L. (2005). Personality development: Stability and change. Annual Review of Psychology, 56, 453-484.

Chan, B. (2006). Big five or big six? Does culture make a difference in researching the prediction of teaching effectiveness? Paper presented at the $36^{\text {th }}$ Annual SCUTREA Conference, 4-06 July 2006. Trinity and All Saints College in Leeds. Retrieved at http://www. leeds.ac.uk/educol/documents/155191.htm on 13 April 2018.

Cheung, F. M., Leung, K., Zhang, J. X., Sun, H. F., Gan, Y. G., \& Song, W. Z. (2001). Indigenous Chinese personality construct: Is the fivefactor model complete? Journal of Cross-Cultural Psychology, 32, 407-433.

Chodubski, A. (2012). Stosunki polsko-ukraińskie: Granice współpracy na poczatku lat 90. XX w [Polish-Ukrainian relations: The boundaries of cooperation in the early 90 s of the 20th century]. Nowa Polityka Wschodnia, 1, 131-150.

Church, A. T. (2000). Culture and personality: Toward an integrated cultural trait psychology. Journal of Personality, 68, 651-704.

Cukur, C. S., De Guzman, M. R. T., \& Carlo, G. (2004). Religiosity, values, and horizontal and vertical individualism - Collectivism: A study of Turkey, the United States, and the Philippines. The Journal of Social Psychology, 144(6), 613-634.

Fiske, A. P. (2002). Using individualism and collectivism to compare cultures - A critique of the validity and measurement of the constructs: Comment on Oyserman et al. (2002). Psychological Bulletin, 128(1), 78-88.

Gonzáles Gutiérrez, J. L., Moreno-Jiménez, B., Garrosa Fernández, E., \& Peñacoba Puente, C. (2005). Personality and subjective well-being: Big five correlates and demographic variables. Personality and Individual Differences, 38, 1561-1569.

Gosling, S. D., \& Vazire, S. (2002). Are we barking up the right tree? Evaluating a comparative approach to personality. Journal of Research in Personality, 36(6), 607-614.

Gosling, S. D., Rentfrow, P. J., \& Swann Jr., W. B. (2003). A very brief measure of the Big-Five personality domains. Journal of Research in Personality, 37, 504-528.

Hambleton, R. K., Merenda, P. F., \& Spielberger, C. D. (Eds.). (2004). Adapting educational and psychological tests for cross-cultural assessment. Psychology Press. Mahwah: Erlbaum.

Hofstede, G. (2001). Culture's consequences: Comparing values, behaviours, institutions and organisations across nations. London: SAGE Publications.

Hofstede, G., \& McCrae, R. R. (2004). Personality and culture revisited: Linking traits and dimensions of culture. Cross-Cultural Research, 38(1), 52-88. 
Hofstede, G., Hofstede, G. J., \& Minkov, M. (2010). Cultures and organisations, software of the mind: Intercultural cooperation and its importance for survival. New York: McGraw Hill.

Hornowska, E., \& Paluchowski, W. (2004). Kulturowa adaptacja testów psychologicznych [cultural adaptation of psychological texts]. In J. Brzeziński (Ed.), Metodologia badań psychologicznych. Wybór tekstów [Methodology of psychological research. Selected works] (pp. 151-191). Warszawa: PWN.

Hosseinkhanzadeh, A. A., \& Taher, M. (2013). The relationship between personality traits with life satisfaction. Sociology Mind, 3(1), 99-105.

https://www.psychometrica.de/correlation.html, Retrieved 08.04.2019.

Kamakura, T., Ando, J., \& Ono, Y. (2007). Genetic and environmental effects of stability and change in self-esteem during adolescence. Personality and Individual Differences, 42(1), 181-190.

Karpenko, E. (2018). Measurement od individualism and collectivism. Ukrainian adaptation of Individualism-Collectivism Scale. Unpublished research report. Drohobych: Ivan Franko Pedagogical State University.

Krueger, R. F., \& Johnson, W. (2010). Behavioural genetics and personality. In O. P. John, R. W. Robins, \& L. A. Pervin (Eds.), Handbook of personality: Theory and research (pp. 287-310). New YorkLondon: The Guilford Press.

Kwiatkowska, A. (2009). "Zróżnicowanie kulturowe świata a rozwój gospodarczy - czy mapa bogactwa i biedy pokrywa się z kulturowa mapa świata" [Cultural diversity of the world and economic development: Does the map of wealth and poverty match the cultural map?]. Zeszyty Naukowe WSZiP im. Heleny Chodkowskiej, 4(33), 5-32.

Larsen, R. J., \& Buss, D. M. (2010). Personality psychology: Domains of knowledge about human nature. New York: McGraw Hill Education.

Laursen, B., Pulkkinen, L., \& Adams, R. (2002). The antecedents and correlates of agreeableness in adulthood. Developmental Psychology, 38(4), 591-603.

Leitner D. (2009). The relationship between well-being, sleep, benevolence and personality. Master's thesis, University of British Columbia.

Lynn, R. (1981). Cross-cultural differences in neuroticism, extraversion and psychoticism. In R. Lynn (Ed.), Dimensions of personality (pp. 263-286). Oxford: Pergamon.

Maccoby, E. E. (2000). Parenting and its effects on children: On reading and misreading behaviour genetics. Annual Review of Psychology, 5l(1), 1-27.

Markus, H. R., \& Kitayama, S. (1998). The cultural psychology of personality. Journal of Cross-Cultural Psychology, 29(1), 63-87.

McAdams, D. P., \& Pals, J. L. (2006). A new Big Five: fundamental principles for an integrative science of personality. American Psychologist, 61(3), 204-217.

McCrae, R. R. (2000). Trait psychology and the revival of personality and culture studies. The American Behavioral Scientist, 44(1), 10-31.

McCrae, R. R. (2001). Trait psychology and culture: Exploring intercultural comparisons. Journal of Personality, 69(6), 819-846.

McCrae, R. R., \& Allik, J. (2002). Introduction. In J. Allik (Ed.), The fivefactor model of personality across cultures (pp. 1-4). Springer Science \& Business Media.

McCrae, R. R., \& Costa, P. T. J. (1996). Toward a new generation of personality theories: Theoretical contexts for the five-factor model. The five-factor model of personality (pp. 51-87). New York: Guilford Press.

McCrae, R. R., \& Costa Jr, P. T. (1997). Conceptions and correlates of openness to experience. In: Handbook of personality psychology (pp. 825-847). Academic Press.

McCrae, R. R., \& Costa Jr., P. T. (1991). Adding Liebe und Arbeit: The full five-factor model and well-being. Personality and Social Psychology Bulletin, 17(2), 227-232.

McCrae, R. R., Costa Jr., P. T., Ostendorf, F., Angleitner, A., Hřebíčková, M., Avia, M. D., et al. (2000). Nature over nurture: Temperament, personality, and le span development. Journal of Personality and Social Psychology, 78(1), 173-186.

Nelis, D., Kotsou, I., Quoidbach, J., Hansenne, M., Weytens, F., Dupuis, P., \& Mikolajczak, M. (2011). Increasing emotional competence improves psychological and physical well-being, social relationships, and employability. Emotion, 11(2), 354.

Realo, A., Allik, J., \& Vadi, M. (1997). The hierarchical structure of collectivism. Journal of Research in Personality, 31(1), 93-116.

Schwartz, S. H. (2004). Mapping and interpreting cultural differences around the world. In H. Vinken, J. Soeters, \& P. Ester (Eds.), Comparing cultures: Dimensions of cultures in a comparative perspective (pp. 43-73). Leiden: Brill.

Schwartz, S. H. (2008). Cultural value orientations: Nature and implications of national differences. Moscow: Publishing house of SU HSE.

Serebryakova, T. Y. A., Morozova, L. B., Kochneva, E. M., Zharova, D. V., Kostyleva, E. A., \& Kolarkova, O. G. (2016). Emotional stability as a condition of students' adaptation to studying in a higher educational institution. International Journal of Environmental and Science Education, 11(15), 7486-7494.

Singelis, T. M., Triandis, H. C., Bhawuk, D. P., \& Gelfand, M. J. (1995). Horizontal and vertical dimensions of individualism and collectivism: A theoretical and measurement refinement. Cross-Cultural Research, 29(3), 240-275.

Sorokowska, A., Słowińska, A., Zbieg, A., \& Sorokowski, P. (2014). Polska adaptacja testu Ten Item Inventory (TIPI) - TIPI-PL - wersja standardowa $i$ internetowa [Polish Adaptation of Ten Item Inventory (TIPI) - TIPI-PL - Standard and Internet veriosn]. Wrocław: WrocLab.

Sprynska, Z. (2018). Ukrainian version of Ten Item Personality InventoryUkrainian version of Ten Item Personality Inventory. Drohobych: Ivan Franko Pedagogical State University.

Stojanowska, E., \& Baj, M. (2017). Zadowolenie ze studiów u osób z różnym nasileniem orientacji społecznych ja. Rola doświadczenia zdobywanego na studiach [Satisfaction with the study among students with different level of social orientations of self. The role of experience gained in college]. Studia Psychologica: Theoria et praxis, 2(16), 23-42.

Strus, W., Cieciuch, J., \& Rowiński, T. (2014). Polska adaptacja kwestionariusza IPIP-BFM-50 do pomiaru pieciu cech osobowości w ujęciu leksykalnym [The Polish adaptation of the IPIP-BFM-50 questionnaire for measuring five personality traits in the lexical approach]. Roczniki Psychologiczne, 17(2), 327-346.

Tanksale, D. (2015). Big Five personality traits: Are they really important for the subjective well-being of Indians? International Journal of Psychology, 50, 64-69.

Tanner, J. L., \& Arnett, J. J. (2016). The emergence of emerging adulthood: The new life stage between adolescence and young adulthood. In A. Andy Furlong (Ed.), Routledge Handbook of Youth and Young Adulthood (pp. 50-56). London: Routledge.

Triandis, H. C. (1989). The self and social behaviour in differing cultural contexts. Psychological Review, 96, 506-520.

Triandis, H. C. (1995). Individualism and collectivism. Boulder, CO: Westview Press.

Triandis, H. C. (2001). Individualism-collectivism and personality. Journal of Personality, 69(6), 907-924.

Triandis, H. C. (2018). Individualism and collectivism. New York: Routledge.

Triandis, H. C., \& Suh, E. M. (2002). Cultural influences on personality. Annual Review of Psychology, 53(1), 133-160.

Triandis, H. C., Leung, K., Villareal, M. J., \& Clack, F. I. (1985). Allocentric versus idiocentric tendencies: Convergent and discriminant validation. Journal of Research in Personality, 19(4), 395-415.

Van Widenfelt, B. M., Treffers, P. D., De Beurs, E., Siebelink, B. M., \& Koudijs, E. (2005). Translation and cross-cultural adaptation of assessment instruments used in psychological research with children 
and families. Clinical Child and Family Psychology Review, 8(2), $135-147$.

Vogt, L. T. (2007). The relationship between the five-factor model and individualism/collectivism among South African students. $\mathrm{PhD}$ dissertation, University of the Witwatersrand.

Vogt, L., \& Laher, S. (2009). The five factor model of personality and individualism/collectivism in South Africa: An exploratory study. Psychology in Society, 37, 39-54.

Wampold, B. E., \& Freund, R. D. (1987). Use of multiple regression in counseling psychology research: A flexible data-analytic strategy. Journal of Counseling Psychology, 34(4), 372-382.
Ward, C., Leong, C., \& Low, M. (2004). Personality and sojourner adjustment: An exploration of the big five and the cultural fit proposition. Journal of Cross-Cultural Psychology, 35(2), 137-151.

www.studyinpoland.pl, Retrieved 04.01.2018.

Zarzycka, B., Tychmanowicz, A., \& Goździewicz-Rostankowska, A. (2016). The interplay between religiosity and horizontal and vertical individualism-collectivism among Polish Catholic students. Polish Psychological Bulletin, 47(3), 383-393.

Publisher's Note Springer Nature remains neutral with regard to jurisdictional claims in published maps and institutional affiliations. 